\title{
Isolierte Hepatomegalie als Manifestation eines atypischen Burkitt-Lymphoms
}

\section{Einführung \\ $\nabla$}

Die Non-Hodgkin-Lymphome stellen eine sehr heterogene Gruppe von Neoplasien dar. Unter den peripheren B-Zell-Non-Hodgkin-Lymphomen hat das Burkitt-Lymphom mit einem Vorkommen von 30\% aller Lymphome im Kindesalter die größte Relevanz. Das Burkitt-Lymphom ist die aggressivste aller lymphoproliferativen Erkrankungen. Nach WHO-Richtlinien unterscheidet man die endemische, sporadische und HIV-assoziierte Form (H. Gadner et al. Pädiatrische Hämatologie und Onkologie 2006; 63: 732751 ). Die sporadische Form tritt vor allem in den europäischen Ländern auf. In $80 \%$ der Fälle liegt bei der sporadischen Form eine Translokation des c-Myc-Gens von Chromosom 8 vor (J. A. Ferry et al. The Oncologist 2006; 11:375-383). Klinisch manifestieren sich sporadische Burkitt-Lymphome meist als abdominelle oder tonsilläre Tumoren, die im Kindesalter häufig einen leukämischen Verlauf nehmen, der durch einen Befall des Knochenmarks von $>25 \%$ definiert ist. Knochenmark- und ZNS-Befall kommen bei allen Varianten vor. Aufgrund der hohen Proliferationsrate der Lymphome mit konsekutiv großen Tumormassen ist das Tumorlyse-Syndrom zu Beginn der Chemotherapie eine gefürchtete Komplikation. Therapeutisch sprechen die großzelligen Lymphome jedoch sehr gut auf intensive Chemotherapie an, sodass mit ihrer Einführung und stetigen Optimierung die vormals schlechte Prognose auf eine 5-Jahres-Überlebensrate von über $90 \%$ bei begrenzter Tumorausbreitung (Stadium I nach der Murphy/ St. Jude-Klassifikation) verbessert werden konnte. Auch Patienten mit disseminierter Tumorausbreitung (Stadium III) weisen inzwischen ein 5-Jahres-Überleben von ca. $65 \%$ auf.

\section{Isolated Hepatomegaly as Manifestation of Atypical Burkitt's Lymphoma}

\section{Introduction}

Non-Hodgkin lymphomas represent a very heterogeneous group of neoplasias. Among peripheral B-cell non-Hodgkin lymphomas, Burkitt's lymphoma is most relevant with an occurrence rate of $30 \%$ of all lymphomas in children. Burkitt's lymphoma is the most aggressive of all lymphoproliferative disorders. According to the WHO guidelines, a differentiation is made between endemic, sporadic, and HIV-associated types (H. Gadner et al. Pediatric Hematology and Oncology 2006; 63: 732-751). The sporadic type primarily occurs in European countries. In $80 \%$ of cases, there is translocation of the c-Myc gene of chromosome 8 in the sporadic type (J. A. Ferry et al. The Oncologist 2006; 11: 375383). Sporadic Burkitt's lymphomas typically manifest clinically as abdominal or tonsillar tumors that frequently follow a leukemic course in children defined by involvement of the bone marrow of $>25 \%$. Bone marrow and CNS involvement occur in all variants. Due to the high proliferation rate of lymphomas with consecutive large tumor masses, tumor lysis syndrome is a possible complication at the start of chemotherapy. However, large-cell lymphomas respond well to intensive chemotherapy and its introduction and continuous optimization have improved the previously poor prognosis to a 5 -year survival rate of over $90 \%$ with limited tumor spread (stage I according to the Murphy/St. Jude classification). Patients with disseminated tumor spread (stage III) also now have a 5-year survival rate of approx. $65 \%$.

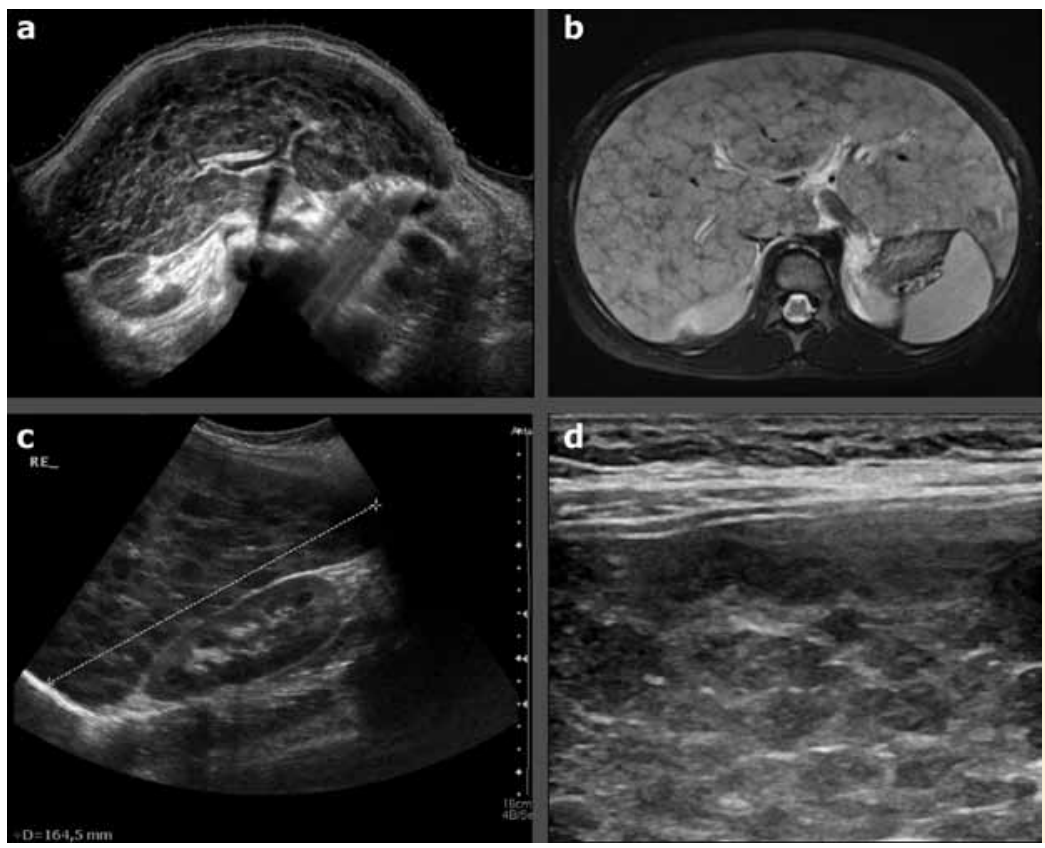

Abb. 1 Sonografische und MRT-Befunde der Leber bei Erstvorstellung.

(a) Panoramaansicht im Oberbauch-Transversalschnitt in der Sonografie und (b) in der MRT (T2-Wichtung) zeigt kleinknotige Binnenstruktur der Leber. (c) Vergrößerte Leber in der vorderen Axillarlinie mit $16.5 \mathrm{~cm}$ Länge mit (d) multiplen echoarmen Knoten in der sonografischen Detailaufnahme (Siemens Antares/GE Loqiq E9).

Fig. 1 Ultrasound and MRI findings at presentation. Small lumps in the inner structure of the liver were seen with ultrasonography in a (a) panorama view of the upper abdomen and a transverse cut and (b) in MRI (T2-weighted). (c) Ultrasound imaging shows an enlarged liver in the anterior axillary line (16.5 cm length) with (d) multiple hypoechoic lumps (Siemens Antares/GE Loqiq E9). 


\section{Fallbeschreibung}

$\nabla$

Ein 8-jähriger Junge kommt zum Ausschluss einer Appendizitis mit seit 5 Tagen bestehenden Bauchschmerzen und postprandialem Erbrechen (ein bis 2-mal täglich) in die Notaufnahme. Fieber habe zu keinem Zeitpunkt bestanden, der Appetit sei mäßig, aber Nachtschweiß oder Gewichtsabnahme seien nicht zu verzeichnen. In der Untersuchung lässt sich eine massive Hepatomegalie mit bis in den rechten Unterbauch reichender Leber und druckschmerzhafter Oberfläche feststellen. Die übrige Untersuchung ist unauffällig (kein Ikterus, keine Leberhautzeichen, keine Splenomegalie). Die anschließend durchgeführte Sonografie bestätigt die ausgeprägte, fast das gesamte Abdomen ausfüllende Hepatomegalie (Abb. 1). Eine grobknotig konfigurierte Leber (Knotengröße 10-13 mm) mit multiplen echoarmen Herden und fibrotischem Umbau kommt zur Darstellung. Die Oberfläche ist grobhöckrig, die Leber- und Portalvenenstruktur erhalten, wenn auch durch imprimierende Knoten deformiert. Der gesamte übrige Oberbauchstatus ist sonografisch unauffällig (insbesondere keine Splenomegalie, keine vergrößerten abdominellen Lymphknoten und keine Zysten). Durch einen klinisch erfahrenen Ultraschalldiagnostiker wurde die Verdachtsdiagnose eines Lymphoms der Leber oder eines Stoffwechseldefekts gestellt. Anamnestisch finden sich bei dem Patienten bis auf eine Invagination im Alter von einem Jahr keine Vorerkrankungen; die Familienanamnese ist ebenfalls leer. Laborchemisch war bei Aufnahme lediglich eine marginale Erhöhung der Transaminasen zu verzeichnen. Blutbild, Bilirubin, LDH, Nierenretentionsparameter, Gerinnung und Entzündungswerte waren normwertig, die Leberfunktion war nicht beeinträchtigt. Die Diagnostik hinsichtlich Stoffwechselerkrankungen und Infektionen ergab bis auf ein positives EBV-IgG im Serum keine auffälligen Befunde. Die am ersten stationären Tag durchgeführte, sonografisch gesteuerte Leberbiopsie bestätigte die Verdachtsdiagnose. In dem Stanzzylinder fanden sich großflächige Infiltrate einer malignen Neoplasie mit degenerativen Veränderungen der Hepatozyten (@Abb. 2). Die Tumorzellen exprimierten CD20, CD10 und schwach CD99 und fil1, was zu dem Vorliegen eines hochmalignen B-Zell-Lymphoms passt. Immunhistologisch fand sich außerdem eine Expression von bcl6 und kaum bcl2. Mit dem Vorliegen aller für ein Burkitt-Lymphom typischen Parameter, bis auf die klassischerweise positive Translokation im c-myc-Gen, wurde das Lymphom schließlich als atypisches Burkitt-Lymphom klassifiziert. Im weiteren Staging fanden sich in der Lumbal- und Knochenmarkspunktion, der Computer- und Kernspintomografie (OAbb. 1) kein Knochen- oder Knochenmarkbefall und keine ZNS-Beteiligung. Dies entspricht dem Vorliegen eines Stadium III nach der Murphy/St.Jude-Klassifikation und wird nach dem B-NHL-BFM-04Protokoll einer sofortigen Hochdosis-Chemotherapie zugeführt. Die Therapie (R3-Arm) besteht aus einem zytoreduktiven Vorblock (Dexamethason, Cyclophosphamid i.v. und Methotrexat, Cytarabin und Prednisolon i.th.) gefolgt von 5 weiteren Blöcken (2-mal AA24, 1-mal CC und 2-mal BB24). Block AA24 besteht aus einer Kombination von Dexamethason, Vincristin, Methotrexat, Ifosphamid, Etoposid und Cytarabin, Block CC aus Dexamethason, Vindesin, Cytarabin, Etoposid und Methotrexat und Block BB24 aus Dexamethason, Vincristin, Doxorubicin, Cyclophosphamid und Cytarabin (A. Reiter et al. B-NHL BFM 04 Therapieprotokoll, 2nd Ammendment 2010). Der Patient vertrug die Chemotherapie komplikationslos. Nach erfolgreicher Beendigung des 5. Chemotherapie-Blocks und damit dem Abschluss der Chemotherapie war die Leber des Patienten nur noch ca. 2 cm unter dem Rippen-

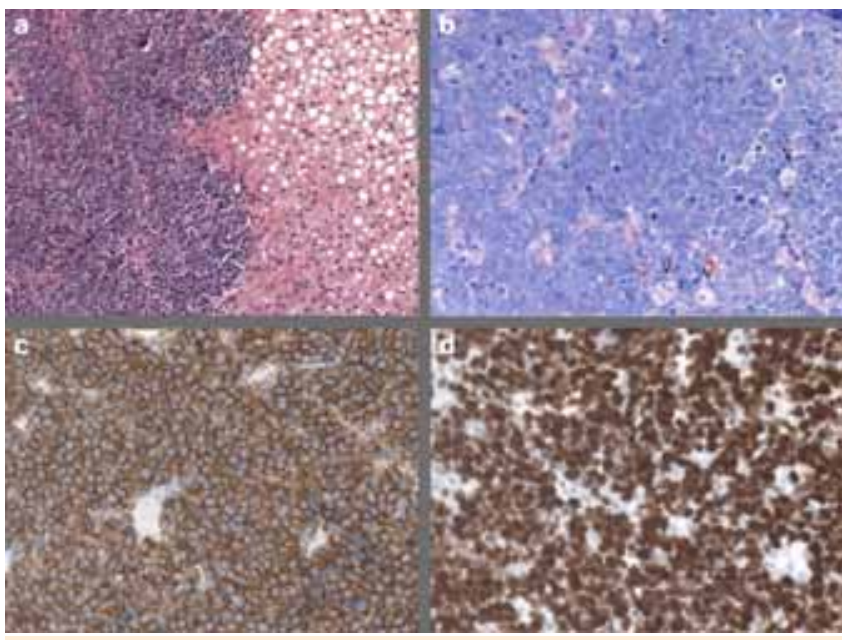

Abb. 2 Histologische Befunde der Leberbiopsie. (a) Das Leberparenchym ist teilweise durch ein dichtes Infiltrat von mittelgroßen, lymphoiden Zellen ersetzt. H\&E, 200x. (b) Die Giemsa Färbung zeigt eine diffuse Proliferation atypischer Zellen mit mittelgroßen Nuclei, kleinen Nucleoli und nur einem schmalen, basophilen Cytoplasmasaum.Die Mitoseaktivität ist hoch, und man findet viele apoptotische Zellen und starry-sky-Makrophagen (Pfeile). Giemsa, 400x. (c) Das neoplastische Infiltrat ist stark positiv für den B-Zell Marker CD20. Immunoperoxidase, 400x. (d) Die durch MIB-Färbung dargestellte Proliferationsrate beträgt 100\%. Immunoperoxidase, 400x.

Fig. 2 Histological findings in the liver biopsy. (a) The liver parenchyma is partly replaced by a dense infiltrate of medium-sized lymphoid cells. H\&E, 200x. (b) Giemsa staining shows diffuse proliferation of atypical cells with medium-sized nuclei with small nucleoli and a narrow rim of basophilic cytoplasm. Mitotic activity is high, and there are many apoptotic bodies and starry sky macrophages (arrow heads). Giemsa, 400x. (c) The neoplastic infiltrate is strongly positive for the B-cell marker CD20. Immunoperoxidase, 400x. (d) The proliferation rate, assessed by MIB1 staining, is virtually $100 \%$. Immunoperoxidase, 400x.

\section{Case description}

An eight-year-old boy experiencing stomach pain and postprandial vomiting (once to twice daily) for five days came to the emergency room to rule out appendicitis. He did not have fever, had a moderate appetite and night sweats and weight loss were not recorded. Massive hepatomegaly with the liver extending into the right lower abdomen and surface pressure pain were detected in the examination. The rest of the examination was normal (no jaundice, no signs of liver disease in the skin, no splenomegaly). The subsequently performed ultrasound examination confirmed the pronounced hepatomegaly almost filling the entire abdomen (oFig. 1). A liver with large lumps (lump size $10-13 \mathrm{~mm}$ ) with multiple hypoechoic tumors and fibrotic tissue was visualized. The surface was nodular. The liver and portal vein structure were intact but deformed by the impression of lumps. The remaining upper abdomen status was normal on ultrasound (in particular no splenomegaly, no enlarged abdominal lymph nodes and no cysts). The tentative diagnosis of lymphoma of the liver or a metabolic defect was made by a clinically experienced ultrasound examiner. The patient history did not include any previous diseases other than an invagination at the age of one. The family history was also normal. Laboratory tests at the time of admission showed only a marginal increase in the transaminases. The blood count, bilirubin, LDH, renal retention parameters, clotting, and inflammatory parameters were all normal and the liver function was not affected. Except for a positive EBV-IgG in the serum, the diagnostic results regarding metabolic diseases were normal. The ultrasound-guided liver biopsy performed on the first day of 
bogen tastbar. Sonografisch ließ sich eine weiterhin noch leicht vergrößerte Leber mit unauffälliger Struktur darstellen ( $\triangle \mathbf{A b b}$. 3). Klinisch ging es dem Patienten nach Abschluss der Chemotherapie gut, Leber- und Nierenfunktion waren unbeeinträchtigt, Hinweise auf chemotherapiebedingte Folgeschäden ergaben sich zu dem Zeitpunkt nicht.

\section{Diskussion}

\section{$\nabla$}

Non-Hodgkin-Lymphome stellen im Gegensatz zu den HodgkinLymphomen eine sehr heterogene Gruppe von malignen Erkrankungen mit entarteten Vorläufer- oder reifen B- und T-Zellen dar, die gehäuft bei Heranwachsenden vorkommen. Häufig findet man ausgeprägte tonsilläre oder mediastinale Tumoren, die dann mit Husten, Atembeschwerden oder inspiratorischem Stridor apparent werden können. Zudem kommen auch primär leukämische Verläufe von Non-Hodgkin-Lymphomen vor (H. Gadner et al., Pädiatrische Hämatologie und Onkologie 2006; 63: 732-751). Die typische Manifestation der sporadischen Burkitt-Lymphome ist die Ileozökalregion. Ovarien, Nieren, das Omentum oder der Waldeyer'sche Rachenring können ebenfalls betroffen sein. So werden sporadische Burkitt-Lymphome häufig durch abdominelle Beschwerden aufgrund von Blutungen, Obstruktionen oder vorgetäuschten Appendizitiden klinisch apparent (K. A. Blum et al. Blood 2004; 104:3009-3020). Ein isolierter Leberbefall, wie die hier beschriebene massive Hepatomegalie, ist als ausschließliche Manifestation eine ausgesprochene Rarität. Bisher sind nur wenige Fälle, darunter der Fall eines 19-Jährigen mit ähnlicher Präsentation in Korea beschrieben. Aufgrund dieser Manifestation war eine Diagnostik in Richtung Stoffwechselerkrankungen, zum Ausschluss eines Morbus Wilsons beispielsweise, indiziert. Außerdem sollten bei einer Hepatomegalie im Kindesalter weitere Differenzialdiagnosen in Betracht gezogen und ausgeschlossen werden: entzündliche Erkrankungen (Virushepatitis, bakterielle Infektionen, Parasitosen, Autoimmunhepatitis, primärsklerosierende Cholangitis, Sarkoidose), cholestatische Erkrankungen (progressive familiäre intrahepatische Cholestasesyndrome (PFIC), Cholangitis), iatrogene Ursachen (Medikamente, parenterale Ernährung), Herz-/Gefäßerkrankungen (Rechtsherzversagen, Budd-Chiari-Syndrom, Venenverschlusskrankheit), Raumforderungen (Hepatoblastom, fokale noduläre Hyperplasie, hepatozelluläres Karzinom, Neuroblastom, Zysten, Hämatome, Hämangiome, Echinokokken, Amöbenleberabszess), Infiltrative Erkrankungen (Lymphome, Leukämien, Histiozytosen) und hämolytische Anämien (Sichelzellanämie), der Morbus Osler oder das Klippel-Trenaunay-Syndrom (modifiziert, nach Rodeck, Zimmer. Pädiatrische Gastroenterologie, Hepatologie und Ernährung, 1. Auflage, Springer 2008:Seite 331). inpatient care confirmed the tentative diagnosis. The punch biopsy cylinder contained large-area infiltrates of a malignant neoplasia with degenerative changes of the hepatocytes (oFig. 2). The tumor cells expressed CD20, CD10 and weakly expressed CD99 and fil1 which corresponds to the presence of highly malignant B-cell lymphoma. Moreover, immunohistology showed an expression of bcl6 and barely an expression of bcl2. With the presence of all parameters typical for Burkitt's lymphoma except for the typically positive translocation in the c-myc gene, the lymphoma was finally classified as atypical Burkitt's lymphoma. In further staging lumbar and bone marrow puncture, computed tomography, and MRI ( $\odot$ Fig. 1) did not show any bone, bone marrow, or CNS involvement. This corresponds to the presence of stage III according to the Murphy/St. Jude classification and is performed according to the B-NHL BFM 04 protocol of immediate high-dose chemotherapy. Treatment (R3 arm) was comprised of a cytoreductive preliminary block (dexamethasone, cyclophosphamide i.v. and methotrexate, cytarabine and prednisolone i. th.) followed by five additional blocks (two AA24, one CC, and two BB24). Block AA24 was comprised of a combination of dexamethasone, vincristine, methotrexate, ifosfamide, etoposide, and cytarabine, block CC of dexamethasone, vindesine, cytarabine, etoposide and methotrexate and block BB24 of dexamethasone, vincristine, doxorubicin, cyclophosphamide and cytarabine (A. Reiter et al. B-NHL BFM 04 Treatment Protocol, 2nd Amendment 2010). The patient tolerated the chemotherapy without complications. After successful completion of the fifth chemotherapy block and thus the conclusion of chemotherapy, the liver of the patient was still palpable only approximately two $\mathrm{cm}$ below the costal arch. A still slightly enlarged liver with normal structure was visualized with ultrasound ( $\odot$ Fig. 3). The patient was doing well clinically after the completion of chemotherapy, liver and kidney function were not affected, and there were no indications of damage caused by chemotherapy.

\section{Discussion \\ $\nabla$}

In contrast to Hodgkin lymphomas, non-Hodgkin lymphomas are a very heterogeneous group of malignant diseases with degenerated precursor cells or mature B and T-cells that typically occur in adolescents. Pronounced tonsillar or mediastinal tumors are often found and become apparent on the basis of coughing, breathing difficulties, or inspiratory stridor. In addition, primary leukemic processes of non-Hodgkin lymphomas occur (H. Gadner et al., Pediatric Hematology and Oncology 2006; 63: 732-751). The typical manifestation of sporadic Burkitt's lymphomas is the ileocecal region. The ovaries, kidneys, omentum or Waldeyer's ring can also be affected. Therefore, the clinical symptoms of sporadic Burkitt's lymphomas are often abdominal pain due to bleeding,

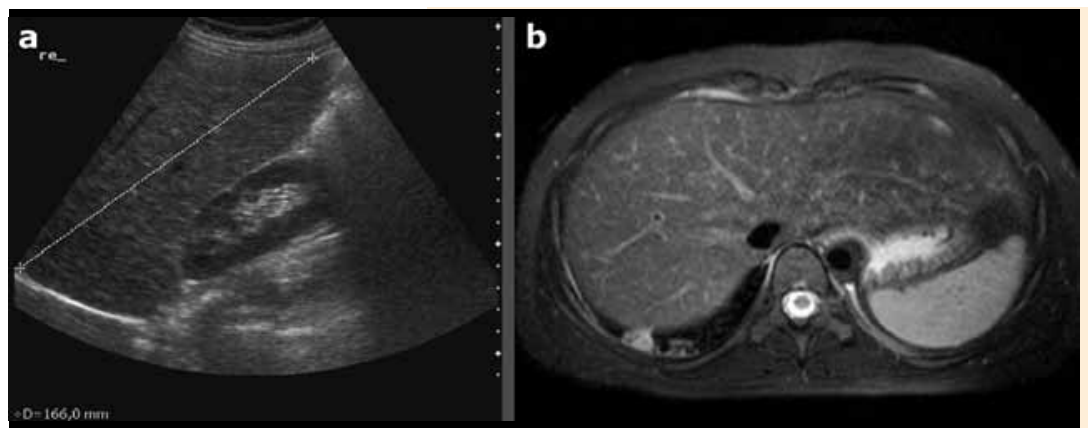

Abb. 3 Sonografische und MRT-Befunde der Leber nach Therapieende. (a) Sonografischer Longitudinalschnitt in der rechten Flanke zeigt eine weiterhin vergrößerte Leber mit jetzt nicht mehr abgrenzbaren Rundherden (SIEMENS Antares $5 \mathrm{MHz}$ ). (b) Ebenfalls normalisierte Leberstruktur in der MRT (T2-Wichtung).

Fig. 3 Ultrasound and MRI findings after chemotherapy. Ultrasound: (a) A longitudinal cut in the right flank shows a still enlarged liver, now without definable round masses (SIEMENS Antares $5 \mathrm{MHz}$ ). (b) MRI findings show a normalized parenchymal liver structure as well (T2-weighted). 
Neben der obligatorischen Biopsie zur histopathologischen Sicherung war die Sonografie in diesem Fall das Diagnostikum der Wahl. Die initiale Verdachtsdiagnose wurde sonografisch gestellt und die weiteren Verlaufskontrollen konnten ebenfalls mittels Ultraschall durchgeführt werden. Zu Beginn war 1. die Charakterisierung der Leberveränderungen wichtig (grob-knotige Struktur), 2. die Beurteilung, ob eine Beteiligung weiterer Bauchorgane (inkl. Lymphknotenbeteiligung) vorlag, und 3. die Einschätzung, ob die Funktion von Leber oder Darm (Pfortaderfluss, Einwachsen in den Darm, Obstruktionen) bereits eingeschränkt war und mit Komplikationen wie einem Leberversagen zu rechnen wäre. Diese Fragestellungen konnten mithilfe einer sonografischen Untersuchung beantwortet werden. Neben dem großen Vorteil der eingesparten Strahlenexposition und Kontrastmittelgabe ist die Sonografie gerade in der Pädiatrie Kernspinuntersuchungen oder Computertomografien wegen der deutlich höheren Praktikabilität vorzuziehen. Notwendig waren zum weiteren Staging (Knochen- oder Knochenmarksbefall, ZNS-Beteiligung) eine Lumbalpunktion, Computertomografie von Thorax und Abdomen und eine Kernspinuntersuchung. Die Kernspinaufnahmen lieferten jedoch im Vergleich zur Sonografie kaum Zugewinn an Information. Während der Chemotherapie wurden ebenfalls Ultraschalluntersuchungen zur Überprüfung des Therapieansprechens durchgeführt, die nach zwei Blöcken, also während des CC-Blocks eine weiterhin stark vergrößerte Leber mit noch inhomogener Parenchymstruktur, aber keine vergrößerten Lymphknoten mehr zeigte. Die Verlaufskontrolle 3 Monate nach Beendigung der Chemotherapie zeigte eine homogen strukturierte Leber mit einer Größe von $15 \mathrm{~cm}$. Da durch die parallel durchgeführten Kernspinaufnahmen kein diagnostischer Mehrwert erzielt wurde, werden die weiteren Kontrollen sonografisch durchgeführt werden können. Sporadische Burkitt-Lymphome können, neben tonsillärer, mediastinaler oder der Manifestation in der Ileozökalregion auch einen isolierten Leberbefall zeigen. Sie sprechen sehr gut auf intensive Chemotherapie an. Die Sonografie eignet sich in dieser Situation ausgezeichnet zum Monitoring des Krankheitsverlaufs.

L. Oevermann ${ }^{1}$, H. P. Haber ${ }^{1}$, J. Schäfer ${ }^{1}$, F. Fend ${ }^{1}$, R. Handgretinger $^{1}$, K. Seitz ${ }^{2}$, M. Ebinger ${ }^{1}$, F. Kassberger ${ }^{3}$

${ }^{1}$ Tübingen

${ }^{2}$ Sigmaringen

${ }^{3}$ Ludwigsburg

\section{Korrespondenzadresse}

lena.oevermann@med.uni-tuebingen.de obstructions, or simulated appendicitis (K. A. Blum et al. Blood 2004; 104: 3009-3020). Isolated liver involvement, such as the massive hepatomegaly described here, as the only manifestation is extremely rare. To date, only a few cases including the case of a 19-year-old with similar presentation in Korea have been described. On the basis of this manifestation, diagnostic investigation in the direction of metabolic diseases to rule out Wilson's disease, for example, was indicated. Moreover, additional differential diagnoses should be taken into consideration and ruled out in the case of hepatomegaly in children: inflammatory diseases (viral hepatitis, bacterial infections, parasitoses, autoimmune hepatitis, primary sclerosing cholangitis, sarcoidosis), cholestatic diseases (progressive genetic intrahepatic cholestasis syndrome, cholangitis), iatrogenic causes (medications, parenteral feeding), cardiac/vascular diseases (right heart failure, Budd-Chiari Syndrome, venous occlusion disease), space-occupying lesions (hepatoblastoma, focal nodular hyperplasia, hepatocellular carcinoma, neuroblastoma, cysts, hematomas, hemangioma, echinococcus cysts, amebic hepatic abscess), infiltrative diseases (lymphomas, leukemias, histiocytoses), and hemolytic anemias (sickle cell anemia), Osler's disease or Klippel-Trenaunay syndrome (modified according to Rodeck, Zimmer, Pediatric Gastroenterology, Hepatology and Nutrition, 1st edition, Springer 2008: page 331).

In addition to the obligatory biopsy for histopathological confirmation, ultrasound was the diagnostic method of choice in this case. The initial tentative diagnosis was made with ultrasound and the subsequent follow-up examinations were also able to be performed using ultrasound. First, it was important to characterize liver changes (structure with large lumps). Second, it was determined whether additional stomach organs were involved (including lymph node involvement). Third, it was assessed whether the function of the liver or gut (portal vein flow, growth into the gut, obstructions) was already limited and whether complications such as liver failure could be expected. These questions could be answered on the basis of ultrasound examination. In addition to the significant advantage of the lack of radiation exposure and contrast medium administration, ultrasound is to be given preference over MRI and computed tomography in pediatrics due to its substantially higher practicability. For further staging (bone, bone marrow, CNS involvement), lumbar puncture, computed tomography of the thorax and abdomen, and an MRI examination were necessary. However, the MRI images did not provide significant new information compared to ultrasound. During chemotherapy, ultrasound examinations were performed to examine the response to treatment and showed a still significantly enlarged liver with a still inhomogeneous parenchyma structure but no enlarged lymph nodes after two blocks, i.e., during the CC block. Follow-up three months after the completion of chemotherapy showed a homogeneously structured liver with a size of $15 \mathrm{~cm}$. Since no added diagnostic value was achieved by the MRI images performed in parallel, additional follow-up examinations can be performed with ultrasound. Sporadic Burkitt's lymphomas can also show isolated liver involvement in addition to tonsillar or mediastinal tumors or manifestation in the ileocecal region. They respond well to intensive chemotherapy. Ultrasound is extremely suitable for monitoring the course of the disease in this situation. 